\title{
PENAMBAHAN TEPUNG LIMBAH UDANG DALAM RANSUM BASAL TERHADAP KARKAS AYAM PEDAGING
}

\section{ADDITION OF SHRIMP WASTE FLOUR INTO BASIC RATION ON BROILER CARCAS}

\author{
AE. Harahap'a, J. Handoko, Rovilaili \\ 1Program Studi Petenakan Fakultas Pertanian dan Peternakan, UIN Sultan Syarif Kasim Riau \\ Jl. H.R. Soebrantas No. 155 KM 15 Tuahmadani Tampan Pekanbaru 28293 \\ aKorespondensi: neniannisaharahap@yahoo.co.id
}

\begin{abstract}
Shrimp waste has high protein to be used as broiler feed. The purpose of this study was to determine the addition of shrimp waste flour into basal ration to carcass weight, life weight, percentage of carcass and abdominal fat in broilers aged between 14 to 35 days. This study used 60 unsexing 1 dayold chicks of Cobb strains $f$ and kept from the age of 0-13 days feed commercial rations while those aged 14-35 days were feed basal rations. A completely radomized design (CRD) was applied with four treatments and five replications consisting three chickens each. The treatments were P0 (ration $+0 \%$ shrimp waste flour), P1 (ration $+2.5 \%$ shrimp waste flour), P2 ration $+5 \%$ shrimp was flour and P3( ration $+7.5 \%$ shrimp was flour). The results of this study indicated that the addition of shrimp waste flour up to the level of $7.5 \%$ has a very significant effect on carcass weight, carcass percentage, abdominal fat of broilers aged between 14 to 35 days. It is concluded that the addition of shrimp waste flour to the level of 7,5\% into the ration has improved broiler carcass.
\end{abstract}

Keywords: waste, shrimp, broiler, carcass

\begin{abstract}
ABSTRAK
Limbah udang memiliki protein tinggi untuk bisa dimanfaatkan sebagai pakan ayam pedaging. Tujuan dari penelitian ini adalah untuk mengetahui penambahan tepung limbah udang dalam ransum basal terhadap berat karkas, bobot hidup, persentase karkas dan lemak abdominal pada ayam pedaging umur 14 sampai 35 hari. Penelitian ini menggunakan 60 ayam pedaging strain Cobb yang berumur 1 (unsexing) dan dipelihara mulai umur 0-13 hari diberikan ransum komersial sedangkan umur 14-35 hari diberikan ransum basal. Metode penelitian ini menggunakan Rancangan Acak Lengkap (RAL) dengan 4 perlakuan dan 5 ulangan disetiap ulangan terdiri dari 3 ekor ayam. Adapun perlakuan yang digunakan terdiri dari : P0 ( ransum $+0 \%$ tepung limbah udang), P1 ( ransum $+2,5 \%$ tepung limbah udang, P2 (ransum $+5 \%$ tepung limbah udang) dan P3 (ransum + $7,5 \%$ tepung limbah udang). Hasil penelitian ini menunjukkan bahwa penambahan tepung limbah udang hingga level $7,5 \%$ memberikan pengaruh sangat nyata $(\mathrm{P}<0,01)$ terhadap bobot karkas, persentase karkas, lemak abdominal ayam pedaging umur 14-35 hari. Disimpulkan bahwa penambahan tepung limbah udang hingga level 7,5\% dalam ransum dapat memperbaiki karkas ayam pedaging

Kata kunci: limbah, udang, ayam pedaging, karkas
\end{abstract}

AE Harahap, J Handoko, Rovilaili. 2020. Penambahan Tepung Limbah Udang Dalam Ransum Basal Terhadap Karkas Ayam Pedaging. Jurnal Peternakan Nusantara 6(1): 21-28

\section{PENDAHULUAN}

Ayam ras pedaging merupakan jenis ras unggulan hasil persilangan dari bangsa-bangsa ayam yang memiliki daya produktivitas tinggi. Adapun di dalam pemeliharaan ayam ras pedaging ini menurut Muharlien (2011) haruslah mempunyai manajemen yang baik. 
Manajemen yang baik untuk pemeliharaan ayam ras pedaging harus sesuai dengan pakan yang diberikan, penggunaan pakan yang baik akan menghasilkan daging ayam ras pedaging yang aman dan sehat. Pakan merupakan faktor paling menentukan dalam usaha ayam ras pedaging. Penggunaan bahan pakan berkualitas untuk penyusunan ransum ternak merupakan persyaratan mutlak yang harus dipenuhi.

Biaya yang dikeluarkan untuk bahan pakan (ransum) pada peternakan unggas adalah biaya terbesar yaitu berkisar 60\% - 70\% dari seluruh biaya produksi. Oleh sebab itu perlu bahan pakan alternatif yang murah dan mudah didapatkan. Salah satu bahan pakan alternatif adalah limbah udang. Limbah udang berpotensi sebagai bahan pakan sumber protein karena proteinnya yang tinggi. Beberapa peneliti melaporkan bahwa kandungan protein limbah udang bervariasi dari $24 \%$, 45\%, 52\%, dan $70 \%$ (Gernat, 2001; Fanimo et al., 2004; Okoye et al., 2005).

Kelemahan dari limbah udang yaitu memiliki kandungan kitin dan kalsium karbonat dalam bentuk komplek ikatan senyawa protein-kitinkalsium karbonat, sehingga "bioavailability" oleh ternak unggas sangat rendah yang menyebabkan pembatasan penggunaanya. Penelitian Okaye et al,. (2005) dan Fanimo et al., (2004) menunjukkan penggunaan limbah udang lebih dari $10 \%$ akan menurunkan bobot badan ayam broiler pada fase starter maupun finisher. Penggunaan limbah udang pada ransum unggas, yaitu hanya dapat dipakai lebih kurang $10 \%$ di dalam ransum ayam broiler (Arellano et al., 1997). Tujuan dari penelitian ini adalah untuk mengetahui penambahan tepung limbah udang dalam ransum basal terhadap berat karkas, bobot hidup, persentase karkas dan lemak abdominal pada ayam pedaging umur 14-35 hari

\section{MATERI DAN METODE}

\section{Materi}

Penelitian dilaksanakan di Laboratorium UARDS (UIN Agriculture Reaseach and Development Station) Fakultas Pertanian dan Peternakan Universitas Islam Negeri Sultan Syarif Kasim Riau. Penelitian ini menggunakan ayam pedaging berumur 1 hari, strain Cobb sebanyak 60 ekor tanpa membedakan jenis kelamin (unsexing) dan dengan rataan bobot badan awal 33 gram dipelihara mulai umur 0-13 hari diberikan ransum komersial sedangkan umur 14-35 hari diberikan ransum basal. Formulasi ransum dibuat dengan menggunakan metode trial and error. Ransum yang diberikan selama penelitian adalah ransum yang disusun sendiri berdasarkan kebutuhan broiler. Kandungan nutrisi bahan penyusun formulasi dan hasil perhitungan nutrisi ransum ayam pedaging dapat dilihat pada Tabel 1 dan 2 .

Tabel 1 Kandungan Nutrisi Bahan Penyusun Ransum

\begin{tabular}{lllllll}
\hline $\begin{array}{l}\text { Bahan } \\
\text { pakan }\end{array}$ & PK & ME & LK & SK & Ca & P \\
\hline $\begin{array}{l}\text { Dedak } \\
\text { Jagung** }\end{array}$ & 8,48 & $3.185,43$ & 6,50 & 2,08 & 0,09 & 0,11 \\
$\begin{array}{l}\text { Dedak } \\
\text { Halus** }\end{array}$ & 7,55 & $1.402,5$ & 2,50 & 9,69 & 0,13 & 0,6 \\
$\begin{array}{l}\text { Tepung } \\
\text { Ikan** }\end{array}$ & 47,7 & $2.219,0$ & 8,00 & 1,99 & 5,24 & 2,5 \\
$\begin{array}{l}\text { Tepung } \\
\text { Limbah }\end{array}$ & 32,6 & $1.984,8$ & 0,75 & 21,3 & 16,9 & 2,3 \\
$\begin{array}{l}\text { Udang* } \\
\text { Bungkil }\end{array}$ & 42,7 & $2.438,5$ & 3,50 & 6,28 & 0,33 & 0,43 \\
$\begin{array}{l}\text { Kedelai** } \\
\text { Minyak }\end{array}$ & 0,00 & $8.800,00$ & 60,41 & 0,00 & 0,00 & 0,00 \\
$\begin{array}{l}\text { Kelapa** } \\
\text { Sumber : }\end{array}$ & $*$ Laboratorium Analisis Hasil Pertanian \\
$\begin{array}{l}\text { Fakultas Pertanian Universitas Riau, 2019 } \\
\text { Falan }\end{array}$ & & & & & \\
\hline
\end{tabular}

\footnotetext{
**Laboratorium Teknologi Hasil Pertanian Universitas Riau, 2018
} 
Tabel 2 Hasil Perhitungan Nutrisi Ransum yang digunakan Selama Penelitian

\begin{tabular}{|c|c|c|c|c|}
\hline \multirow{2}{*}{$\begin{array}{l}\text { Bahan } \\
\text { pakan }\end{array}$} & \multirow[b]{2}{*}{ T0 } & \multicolumn{3}{|c|}{ Perlakuan } \\
\hline & & T1 & $\mathbf{T} 2$ & T3 \\
\hline $\begin{array}{l}\text { Dedak } \\
\text { Jagung }\end{array}$ & 44,00 & 46,00 & 42,00 & 46,00 \\
\hline $\begin{array}{l}\text { Dedak } \\
\text { Halus }\end{array}$ & 22,00 & 20,50 & 26,00 & 18,50 \\
\hline Tepung Ikan & 24,00 & 22,00 & 21,00 & 24,00 \\
\hline $\begin{array}{l}\text { Tepung } \\
\text { Limbah } \\
\text { Udang }\end{array}$ & 0,00 & 2,50 & 5,00 & 7,50 \\
\hline $\begin{array}{l}\text { Bungkil } \\
\text { Kedelai }\end{array}$ & 6,00 & 5,00 & 2,00 & 0,00 \\
\hline $\begin{array}{l}\text { Minyak } \\
\text { Kelapa }\end{array}$ & 4,00 & 4,00 & 4,00 & 4,00 \\
\hline Jumlah & 100 & 100 & 100 & 100 \\
\hline $\begin{array}{l}\text { Kandungan } \\
\text { Nutrisi } \\
\text { Ransum }\end{array}$ & T0 & T1 & T2 & T3 \\
\hline PK (\%) & 21,34 & 20,70 & 19,68 & 20,25 \\
\hline $\begin{array}{l}\text { ME (kkal/kg) } \\
(\%)\end{array}$ & 3218,10 & 3191,36 & 3145,62 & 3114,76 \\
\hline LK $(\%)$ & 7,18 & 6,83 & 7,04 & 6,11 \\
\hline SK (\%) & 4,48 & 4,83 & 5,69 & 5,82 \\
\hline $\mathrm{Ca}(\%)$ & 0,52 & 0,89 & 1,16 & 1,48 \\
\hline $\mathrm{P} \quad(\%)$ & 0,73 & 0,75 & 0,74 & 0,72 \\
\hline
\end{tabular}

Sumber : Perkiraan kandungan nutrisi bahan ransum berdasarkan hitungan trial and error yang mengacu pada Tabel 1

\section{Rancangan Percobaan}

Metode penelitian ini dengan eksperimen menggunakan Rancangan Acak Lengkap (RAL) dengan 4 perlakuan dan 5 ulangan disetiap ulangan terdiri dari 3 ekor ayam sehingga total ayam yang dipelihara sebanyak 60 ekor.

Adapun perlakuan yang digunakan adalah sebagai berikut:

$$
\begin{aligned}
& \text { P0 }=\text { Ransum }+0 \% \text { Tepung Limbah Udang } \\
& \text { P1 }=\text { Ransum }+2,5 \% \text { Tepung Limbah Udang } \\
& \text { P2 }=\text { Ransum }+5 \% \text { Tepung Limbah Udang } \\
& \text { P3 = Ransum }+7,5 \% \text { Tepung Limbah Udang }
\end{aligned}
$$

\section{Peubah yang Diamati}

Peubah yang diamati adalah bobot badan akhir, bobot karkas, lemak abdominal dan persentasi karkas ayam pedaging.

1. Bobot Badan Akhir (g)
Bobot badan akhir diperoleh dari hasil penimbangan setelah dipuasakan selama 8 jam (Rasyaf, 2004).

2. Bobot Karkas Tanpa Kulit (g)

Karkas ayam ras pedaging adalah bagian tubuh ayam setelah proses pemotongan yang dibuang bulu, kulit, darah, kepala, leher, kaki bagian bawah dan organ dalam kecuali paru-paru, jantung dan ginjal (Rizal, 2006; Yao et al., 2006).

3. Persentasi Karkas (\%)

Persentase karkas dihitung dengan membandingkan bobot karkas ayam ras pedaging dengan bobot badan akhir lalu dikalikan 100\% (Scott et al, 1982).

4. Bobot Lemak Abdominal (g)

Lemak abdominal merupakan salah satu komponen lemak tubuh yang terletak pada rongga perut. Bobot lemak abdominal dihitung dengan cara menimbang bobot lemak yang melekat dibagian perut ayam ras pedaging yang meliputi jantung, rempela, dinding perut, ginjal dan kloaka.

dilakukan desinfeksi untuk sanitasi kandang menggunakan desinfeksi kandang yang sudah higienis dibiarkan selama 7 hari. Hal yang sama dilakukan terhadap peralatan kandang sebelum digunakan dicuci dengan air. Pemanasan dan penerangan kandang menggunakan lampu pijar dengan daya 60 watt yang ditempatkan pada setiap petak kandang. Penentuan letak pada kandang dilakukan secara acak dan untuk memudahkan pencatatan masing-masing petak kandang diberi kode sesuai dengan perlakuan yang diberikan.

Pembuatan tepung limbah udang dilakukan dengan proses sebagai berikut: Limbah udang yang diperoleh dari pasar tradisional dibersihkan terlebih dahulu dari benda-benda asing yang melekat. Limbah udang (kulit, kepala, dan ekor) lalu dijemur di bawah sinar matahari sampai kering dengan kadar air 5\%, Limbah udang yang sudah kering digiling sampai hancur untuk proses penghalusan lebih optimal, tepung limbah udang siap digunakan sebagai ransum.

Penempatan perlakuan ayam pada unit kandang penelitian dilakukan secara acak dengan prinsip adanya penyeragaman bobot badan tiap perlakuan dengan cara sebagai 
berikut: Anak ayam umur 1 hari ditimbang bobot badannya dan dicatat, kemudian dimasukkan kedalam unit kandang penelitian 1 sampai 20, hingga pada tiap unit kandang terisi 3 ekor ayam. Setelah didapatkan rata-rata bobot keseluruhan masing-masing unit perlakuan, maka dilakukan penukaran ayam untuk mendapatkan bobot rata-rata setiap unit kandang, sehingga bobot badan rata-rata setiap perlakuan seragam atau homogen.

Pemberian pakan dan minum kepada ayam dilakukan dengan cara pemberian secara berulang, dimana kebutuhan pakan ayam broiler diberikan berdasarkan pada periode umur pemeliharaan yang mengacu pada standar pemberian ransum ayam broiler. Pemberian pakan dan air minum pada saat penelitian dilakukan secara ad libitum dengan berdasarkan kebutuhan standar strain ayam. Pakan yang diberikan ditimbang sesuai dengan kebutuhan pakan dan dikalikan dengan jumlah ayam setiap perlakuan. Pemberian air minum pada penelitian ini dilakukan secara ad libitum tanpa menggunakan obat-obatan dan vitamin.

\section{HASIL DAN PEMBAHASAN}

\section{Bobot Badan Akhir}

Bobot badan akhir adalah bobot hidup ayam ras pedaging pada akhir pemeliharaan yakni umur 35 hari disajikan pada Tabel 3.

Tabel 3 Nilai bobot badan akhir ayam ras pedaging (g/ekor) yang diberi ransum dengan penambahan tepung limbah udang.

\begin{tabular}{cr}
\hline Perlakuan & Rataan \\
\hline P0 & $997,6 \pm 65,93$ \\
P1 & $1.015,2 \pm 109,10$ \\
P2 & $1.054,8 \pm 83,43$ \\
P3 & $1.126,4 \pm 31,15$ \\
\hline
\end{tabular}

Keterangan: $\mathrm{P} 0=($ Ransum Basal $+0 \%$ Tepung Limbah Udang), P1 = (Ransum Basal $+2,5 \%$ Tepung Limbah Udang), P2 = (Ransum Basal $+5 \%$ Tepung Limbah Udang), P3 = (Ransum Basal $+7,5 \%$ Tepung Limbah Udang)

Pemberian tepung limbah udang menunjukan pengaruh tidak nyata $(P>0,05)$ terhadap bobot badan akhir ayam pedaging. Tidak adanya pengaruh yang nyata terhadap bobot badan akhir ayam pedaging antar perlakuan dipengaruhi oleh kandungan nutrisi ransum yang hampir sama setiap perlakuan, sehingga dihasilkan pertambahan bobot badan yang sama pula pada akhir penelitian. Selain hal tersebut diatas, pertambahan bobot badan yang sama pada setiap perlakuan juga disebabkan tepung limbah udang tanpa olahan mempunyai kecernaan yang rendah. Hal ini sejalan dengan penelitian Mirzah et al (2006) menyatakan bahwa tepung limbah udang tanpa olahan memiliki tingkat kecernaan 50\% dibandingkan tepung limbah udang yang mengalami pengolahan memiliki tingkat kecernaan $70,50 \%$.

Selain itu bobot badan akhir erat kaitannya dengan konsumsi ransum dimana konsumsi ransum berbanding lurus dengan pertambahan bobot badan ayam pedaging. Konsumsi ransum pada penelitian ini semakin tinggi penambahan tepung limbah udang dalam ransum semakin meningkat. Adapun nilai konsumsi ransum yaitu 2139,13 ; 2240,60; 2254,73; 2287,66. Wahyu (2004) menyebutkan bahwa faktor-faktor yang mempengaruhi bobot ayam broiler yaitu konsumsi ransum, kualitas ransum, jenis kelamin, lama pemeliharaan dan aktivitas. Uzer et al., (2013) bahwa pertambahan bobot badan sangat berkaitan dengan pakan, dalam hal kuantitas yang berkaitan dengan konsumsi pakan apabila konsumsi pakan terganggu maka akan mengganggu pertumbuhan.

Rataan bobot badan akhir yang diperoleh pada penelitian ini dengan penambahan tepung limbah udang $0 \%, 2,5 \%, 5 \%$, dan 7,5\% menunjukkan bahwa nilai rataan bobot badan akhir ayam pedaging berkisar antara 997,6 1.126,4 gram/ekor. Hasil penelitian ini lebih tinggi dari penelitian Mirzah (2007) menggunakan tepung limbah udang yang diolah dengan filtrat air abu sekam dengan rataan bobot badan akhir ayam broiler berkisar antara 954,28 - 874,76 gram/ekor. Lebih rendah dibandingkan dengan penelitian Noferdiman (2011) dengan menggunakan bungkil sawit fermentasi jamur dengan rataan bobot hidup ayam broiler berkisar antara 1.683,9 - 1.924,5 gram/ekor.

\section{Bobot Karkas}

Karkas unggas adalah unggas yang telah dipotong dan dihilangkan bulu, kepala, kaki bagian bawah dan organ dalam kecuali paruparu, jantung dan ginjal (Rizal, 2006; Yao et al., 2006). Bobot karkas disajikan pada Tabel 4 
Tabel 4 Nilai Bobot Karkas Ayam Ras Pedaging (g/ekor) yang Diberi Ransum Dengan Penambahan Tepung Limbah Udang

\begin{tabular}{cc}
\hline Perlakuan & Rataan \\
\hline P0 & $466,6 \pm 52,20^{\mathrm{a}}$ \\
P1 & $501,4 \pm 74,74^{\mathrm{ab}}$ \\
P2 & $566,0 \pm 74,43^{\mathrm{b}}$ \\
P3 & $641,8 \pm 25,50^{\mathrm{c}}$ \\
\hline
\end{tabular}

Keterangan: $\quad \mathrm{P} 0=($ Ransum Basal $+0 \%$ Tepung Limbah Udang), $\mathrm{P} 1=$ (Ransum Basal $+2,5 \%$ Tepung Limbah Udang), $\mathrm{P} 2=$ (Ransum Basal $+5 \%$ Tepung Limbah Udang), P3 $=$ (Ransum Basal $+7,5 \%$ Tepung Limbah Udang) Superskrip yang berbeda pada kolom yang sama menunjukkan berpengaruh sangat nyata $(\mathrm{P}<0.01)$

Semakin tinggi tingkat penggunaan tepung limbah udang memperlihatkan semakin meningkatnya bobot karkas ayam pedaging. Hal ini diduga karena tepung limbah udah memiliki nilai protein yang tinggi dan zat kitin pada tepung limbah udang masih bisa ditoleransi oleh ayam pedaging. Hal ini sejalan dengan pendapat Arellano et al., (1997) yang menyatakan bahwa zat kitin pada tepung limbah udang bisa digunakan dalam ransum unggas apabila dipakai kurang dari 10\%. Bobot karkas mengikuti bobot badan akhir, yang mana semakin tinggi bobot badan akhir akan menghasilkan bobot karkas yang tinggi pula. Haroen (2003) menjelaskan bahwa pencapaian bobot karkas sangat berkaitan dengan bobot potong dan pertambahan bobot badan. Wahju (2004) menyatakan tingginya bobot karkas ayam ras pedaging ditunjang oleh bobot hidup (potong) yang tinggi. Produksi karkas selain disebabkan oleh bobot potong yang dihasilkan juga dipengaruhi pula oleh penanganan dalam proses pemotongan (Murugesan et al., 2005).

Nilai rataan bobot karkas ayam ras pedaging pada penelitian ini berkisar antara 466,6 g/ekor - 641,8 gram/ekor. Hampir sama dengan hasil penelitian Ramadhani et al, (2016) menghasilkan bobot karkas ayam pedaging yang diberi pakan campuran tepung biji karet berkisar antara 524,20 - 702,20 gram/ekor. Lebih rendah dibandingkan hasil penelitian Wahyuni et al, (2016) bahwa bobot karkas broiler diberi tepung limbah ikan gabus pasir berkisar antara 913,72 - 862,50 gram/ekor.

\section{Persentase Karkas}

Persentase karkas adalah jumlah perbandingan bobot karkas umur 30 hari dan bobot badan akhir dikalikan 100\%. Persentase karkas disajikan pada Tabel 5.

Tabel 5 Nilai Persentase Karkas Ayam Ras Pedaging (\%) yang Diberi Ransum dengan Penambahan Tepung Limbah Udang

\begin{tabular}{cc}
\hline Perlakuan & Rataan \\
\hline P0 & $55,160 \pm 3,19^{\mathrm{a}}$ \\
P1 & $58,546 \pm 11,9^{\mathrm{a}}$ \\
P2 & $64,424 \pm 9,07^{\mathrm{b}}$ \\
P3 & $69,848 \pm 4,36^{\mathrm{b}}$ \\
\hline
\end{tabular}

Keterangan: $\mathrm{P} 0=($ Ransum Basal $+0 \%$ Tepung Limbah Udang), $\mathrm{P} 1=$ (Ransum Basal $+2,5 \%$ Tepung Limbah Udang), $\mathrm{P} 2=($ Ransum Basal $+5 \%$ Tepung Limbah Udang), $\mathrm{P} 3=$ (Ransum Basal $+7,5 \%$ Tepung Limbah Udang) Superskrip yang berbeda pada kolom yang sama menunjukkan berpengaruh sangat nyata $(\mathrm{P}<0.01)$

Pemberian tepung limbah udang menunjukan pengaruh sangat nyata $(\mathrm{P}<0.01)$ terhadap persentase karkas ayam pedaging. Hal ini disebabkan oleh bobot potong dan bobot karkas sangat mempengaruhi besar kecilnya persentase karkas. Pendapat ini didukung oleh teori yang dikemukakan oleh Soeparno (2005) bahwa semakin bertambah bobot potong maka produksi karkas semakin meningkat. Persentase karkas dihitung berdasarkan perbandingan antara bobot karkas dan bobot hidup pada akhir penelitian. Bobot karkas dan bobot hidup penelitian ini tinggi sehingga persentase karkasnya juga tinggi. Dewanti et al, (2013) melaporkan bahwa persentase karkas dipengaruhi oleh bobot potong. Persentase karkas berawal dari laju pertumbuhan yang ditunjukkan dengan adanya pertambahan bobot badan akan mempengaruhi bobot potong yang dihasilkan.

Perlakuan P3 memiliki nilai tertinggi dibandingkan dengan perlakuan P0, P1 dan P2 dengan nilai rataan 55,16\% - 69,848\%. Hasil penelitian ini lebih rendah dari penelitian Sandi et al, (2012) bahwa persentase karkas ayam broiler dengan penambahan ampas tahu dan dedak fermentasi berkisar antara 74,06 79,79\%. Serupa dengan penelitian Septinova dkk., (2009) rataan persentase karkas ayam broiler dengan penambahan limbah udang berkisar antara 62\% - 69\%. Sementara Mahata et al., (2008) menyatakan bahwa rataan persentase karkas ayam broiler berkisar antara $60,97 \%-65,58 \%$. 


\section{Lemak Abdominal}

Lemak abdominal (g/ekor) ayam ras pedaging fase finisher yang diberi tepung limbah udang dalam ransum selama penelitian disajikan pada Tabel 6.

Tabel 6 Nilai Lemak Abdominal Ayam Ras Pedaging (g/ekor) yang Diberi Ransum Dengan Penambahan Tepung Limbah Udang

\begin{tabular}{cc}
\hline Perlakuan & \multicolumn{1}{c}{ Rataan } \\
\hline P0 & $13,00 \pm 1,41^{\mathrm{a}}$ \\
P1 & $14,40 \pm 2,30^{\mathrm{a}}$ \\
P2 & $16,00 \pm 2,12^{\mathrm{a}}$ \\
P3 & $19,00 \pm 2,82^{\mathrm{b}}$ \\
\hline
\end{tabular}

Keterangan: $\mathrm{P} 0=($ Ransum Basal $+0 \%$ Tepung Limbah Udang), P1 = (Ransum Basal $+2,5 \%$ Tepung Limbah Udang), P2 = (Ransum Basal $+5 \%$ Tepung Limbah Udang), P3 = (Ransum Basal $+7,5 \%$ Tepung Limbah Udang) Superskrip yang berbeda pada kolom yang sama menunjukkan berpengaruh sangat nyata $(\mathrm{P}<0.01)$

Pemberian tepung limbah udang berpengaruh sangat nyata $(\mathrm{P}<0.01)$ terhadap nilai lemak abdominal ayam ras pedaging. Hal ini diduga kandungan energi dalam ransum yang digunakan tinggi sehingga lemak abdominal juga meningkat setiap perlakuan. Pernyataan ini sesuai dengan pendapat Maryuni dan Wibowo (2005) bahwa pertumbuhan lemak dipengaruhi oleh komposisi ransum terutama tingkat energi dalam ransum. Selain itu disebabkan juga oleh kandungan serat kasar pada tepung limbah udang dapat meningkatkan kandungan lemak abdominal pada ayam ras pedaging, serat kasar tepung limbah udang sebesar 21,29\% Mirzah et al, (2006). Kandungan serat kasar yang tinggi dapat mempengaruhi lemak abdominal broiler. Menurut Zuprizal dan Kamal (2005) bahwa batasan serat kasar dalam pakan ayam broiler tidak boleh lebih dari 4 sampai 4,5\%. Tinggi rendahnya bobot lemak abdominal yang dihasilkan terjadi karena energi yang merupakan hasil dari proses metabolisme zat gizi yang masuk ke dalam tubuh ayam melebihi tingkat kebutuhan yang diperlukan oleh tubuh itu sendiri, baik itu untuk hidup pokok maupun untuk berproduksi (Oktaviana et al, 2010).

Perlakuan P3 memiliki nilai tertinggi dibandingkan dengan perlakuan P0, P1 dan P2 dengan nilai rataan $13,00-19,00$ atau $0,13 \%$ $0,19 \%$. Hasil penelitian ini lebih rendah dari penelitian Septinova et al,, (2009) menggunakan limbah udang terolah mendapatkan lemak abdominal sebesar 0,68\% - 1,37\%. Lebih rendah lagi dari hasil penelitian Salam et al, (2013) bahwa persentase lemak abdominal karkas broiler menggunakan tepung jintan hitam berkisar antara $0,73 \%$ sampai 3,78\%. Hampir sama dengan hasil penelitian yang dilaporkan Mahata et al., (2008) persentase lemak abdominal yaitu 0,50 - 0,61\%. Hampir sama juga dengan penelitian Sudiyono et al, (2013) menggunakan eceng gondok fermentasi persentase lemak abdominalnya berkisar antara $0,59-0,66 \%$.

\section{KESIMPULAN DAN IMPLIKASI}

\section{Kesimpulan}

Penambahan tepung limbah udang hingga level $7,5 \%$ dalam ransum dapat memperbaiki karkas ayam pedaging meliputi; bobot karkas, persentase karkas dan lemak abdominal pada ayam ras pedaging

\section{Implikasi}

Penelitian ini dapat dilanjutkan dengan penambahan taraf pemberian tepung limbah udang terhadap ayam pedaging dengan terlebih dahulu melakukan berbagai teknologi pengolahan pakan

\section{DAFTAR PUSTAKA}

Arellano L. Carillo L, Perez-Gill F, Avila E, Ramos F. 1997. Shrimp head meal utilization in broiler feeding. Poultry. Sciences. 76:85-91.

Dewanti R, Irham M, Sudiyono. 2013. Pengaruh penggunaan eceng gondok (Eichornia crassipes) terfermentasi dalam ransum terhadap persentase karkas, non - karkas, dan lemak abdominal itik lokal jantan umur delapan minggu. Prosiding Seminar Nasional Fakultas Agroindustri Universitas Mercu Buana, Yogyakarta.

Fanimo A. Mudama OE, Umukoro TO,Ougawa 00. 2004. substitusi of Shrimp waste for fish meal in broiler chiken ratio. Tropikal Agricultur. 73:201-205.

Gernat AG. 2001. The effect of using different levels of shrimp mealinlaying hen diets. Poultry. Sciences. 80: 633-636. 
Haroen U. 2013. Respon Ayam Broiler yang Diberi Tepung Daun Sengon (Albizzia falcataria) dalam Ransum terhadap Pertumbuhan dan Hasil Karkas. J. Ilmiah Ilmu-Ilmu Peternakan. 6 (1) : 34-41.

Mahata ME, Dharma A, Ryanto I, Rizal Y. 2008. Effec of Substituting Shrimp Waste Hydrolysate of Penaeus merguensis for Fish Meal in Broiler Performance. Pakistan Journal of Nutrition 7(6):806-810.

Maryuni SS, Wibowo SH. 2005. Pengaruh kandungan lisin dan energi metabolism dalam ransum yang mengandung ubi kayu fermentasi terhadap konsumsi ransum dan lemak ayam broiler. J. Indon.Trop.Animal Agrikultur., 30(1):26-33.

Mirzah, Yumaihana, Filawati. 2006. Pemakaian Tepung Limbah Udang Hasil Olahan sebagai Pengganti Tepung Ikan dalam Ransum Ayam Broiler. Jurusan Nutrisi dan Makanan Ternak Fakultas Peternakan Universitas Andalas. Padang. Sumatera Barat.

Mirzah. 2007. Penggunaan Tepung Limbah Udang yang diolah dengan Filtrat Air Abu Sekam dalam Ransum Ayam Broiler. Universitas Andalas. Media Peternakan. hlm. 189-197.

Muharlien. 2011. Ilmu Ternak Unggas. UB Press. Malang.

Murugesan G, Sathiskumar SM, Swarninathan K.2005. Suplementation of Waste Tea Fungal Biomass as a Dietary Ingredient for Broiler Chicken. Bioresource Technol. 96: 1743-1748.

Noferdiman. 2011. Penggunaan bungkil inti sawit fermentasi oleh jamur Pleuroitus ostrestus dalam ransum terhadap performans ayam broiler. Jurnal Ilmiah Ilmu-IImu Peternakan. 14:35-43.

Oktaviana, D., Zuprizal, Suryanto E. 2010. Pengaruh Penambahan Ampas Virgin Coconut Oil dalam Ransum terhadap Performans dan Produksi Karkas Ayam Broiler. Buletin Peternakan. 34: 159-164.

Okoye FC, Ojewola GS., Njoku-Onu K. 2005. Evaluation of shrimp waste meal as a probable animal protein source for broiler chicken. Int. Jurnal Poultry Sciences. 12: 456 461.

Ramadhani RA, Prayogi HS, Cholis N. 2016. Korelasi antara tingkat deplesi terhadap bobo panen, pertambahan bobot badan, konsumsi pakan, dan FCR pada ayam pedaging. Fakultas Peternakan. Universitas Brawijaya. Malang.

Rasyaf M. 2004. Beternak Ayam Pedaging. Penebar Swadaya. Jakarta

Rizal Y. 2006. Ilmu Nutrisi Unggas. Andalas University Press. Padang.

Salam S., Fatahilah A., Sunarti D., Isroli. 2013. Berat Karkas dan Lemak Abdominal ayam broiler yang diberi tepung jintan hitam (nigella sativa) dalam ransum selama musim panas. Sains Peternakan. 11 (2): 84-89.

Scott ML, Neisheim MC. Young RJ. 1982. Nutrition of The Chicken. $\quad 3^{r d}$ Ed. M. L. Scott and Associated. Itacha. New York.

Septinova D, Kartini T, Purwaningsih N, Riyanti. 2009. Pemanfaatan Limbah Udang Terolah dalam Ransum terhadap Bobot Hidup, Karkas, Giblet dan Lemak Abdominal Broiler. Jurusan Peternakan. Fakultas Pertanian. Universitas Lampung.

Soeparno. 2005. Ilmu dan Teknologi Daging. Gadjah Mada University Press. Yogyakarta.

Sandi S, Palupi R, Amyesti. 2012. Pengaruh Penambahan Ampas Tahu dan Dedak Fermentasi terhadap Karkas, Usus dan Lemak Abdomen Ayam Broiler. Agrinak. 02 : 1-5.

Steel RG, Torrie JH. 1995. Prinsip dan Prosedur Statistik. Gramedia Pustaka Utama. Jakarta.

Sudiyono I. Muhamad R. Dewanti. 2013. Pengaruh Penggunaan Eceng Gondok (Eichornia crassipes) Terfermentasi dalam Ransum terhadap Persentase Karkas, Non Karkas, dan Lemak Abdominal Itik Lokal Jantan Umur Delapan Minggu. Bulletin Peternakan. 37(1): 19-25.

Uzer F, Iriyanti N, Roesdiyanto. 2013. Penggunaan pakan fungsional dalam ransum terhadap konsumsi pakan dan pertambahan 
bobot badan ayam broiler. J. Ilmiah Peternakan. 1 (1):282-288.

Wahju J. 2004. Ilmu Nutrisi Unggas. Gadjah Mada University Press, Yogyakarta.

Wahyuni HT, Manullang R, Ginting N. 2016. Pemanfaatan Tepung Limbah Ikan Gabus Pasir (Butis amboinensis) sebagai Pengganti Tepung Ikan dalam Ransum Terhadap Karkas Ayam Broiler. Jurnal Peternakan Integratif. 4 (2): 163-172

Yao J , Tian X., H. Xi., J. Han., M. Xu, Wu X. 2006. Effect of Choice Fedding on Performance, Gastrointestinal Development and Feed Utilization of Broiler. J. Anim. Sci 19 : 91-96.
Zuprizal, Kamal M. 2005. Nutrisi dan Pakan Unggas. Jurusan Nutrisi dan Makanan Ternak. Fakultas Petrnakan Universitas Gadjah Mada, Yogyakarta. 